\title{
B CELLS IN MULTIPLE SCLEROSIS
}

\author{
Mark P. Burgoon ${ }^{1}$, Donald H. Gilden ${ }^{1,2}$, and Gregory P. Owens ${ }^{1}$ \\ ${ }^{1}$ Department of Neurology, University of Colorado Health Sciences Center, Denver, CO 80262 \\ ${ }^{2}$ Department of Microbiology, University of Colorado Health Sciences Center, Denver, CO 80262
}

\begin{abstract}
The most common laboratory abnormality in multiple sclerosis (MS) is an increased amount of cerebrospinal fluid IgG and the presence of oligoclonal bands. Despite studies of the humoral response that suggest the involvement of an infectious agent or autoantigen in disease, the major targets of the oligoclonal response are still unknown. Identification of these targets will reveal valuable insights into the cause and pathogenesis of MS and is likely to lead to effective treatment.
\end{abstract}

\section{Keywords \\ Multiple Sclerosis; MS; B cells; antibodies; Oligoclonal Bands; Review; CNS; Central Nervious System; Neurologic Disease; Review}

\section{INTRODUCTION}

Multiple sclerosis (MS) is the most common demyelinating disease of humans. Its prevalence in the United States is 250,000-350,000, resulting in >3,000 deaths a year, and an annual morbidity cost of more than $\$ 2.5$ billion. Most MS patients develop disease between ages $15-45$ years, and disease usually takes a relapsing-remitting course, although young patients infrequently develop chronic progressive MS. When disease starts after age 40 years, it is usually characterized by chronic progression that often produces serious disability within 5-10 years. Thus, late-onset MS patients may "catch up" with those who have had remitting-exacerbating disease for decades. In fact, without a history, it is difficult to distinguish an MS patient who has had remitting-exacerbating disease for 25 years from a late-onset chronic progressive MS patient who has had disease for 5 years.

The cause of MS is unknown. The two leading theories are that disease is infectious, probably viral, or is produced by a host-immune response to an infectious agent or autoantigen. These two theories are not mutually exclusive. Results from several areas of investigation argue for a viral cause of MS. First, epidemiologic studies have identified areas of high and low prevalence of MS, and indicate that migration from a high to a low prevalence area before, but not after puberty, reduces the likelihood of developing MS. Thus, although disease does not usually manifest until after puberty, the agent that causes MS is probably acquired before puberty $(1,2)$. Second, studies of identical twins in which one has MS have shown that only $30 \%$ of second twins develop disease, suggesting that more than a putative susceptible genotype determines disease (3). Third, although the protein of normal human cerebrospinal fluid (CSF) contains up to $13 \% \mathrm{IgG}$, the CSF of MS patients contains 15-30\% IgG and sometimes more, as well as oligoclonal bands (OGBs).

Send correspondence to: Mark P. Burgoon, Ph.D., Department of Neurology, University of Colorado Health Sciences Center, 4200 E. $9^{\text {th }}$ Avenue, Mail Stop B182, Denver, CO 80262, Tel: 303-315-3727, Fax: 303-315-8720, mark.burgoon@uchsc.edu. 
The latter are found almost exclusively in central nervous system (CNS) disorders of infectious origins, such as neurosyphilis, tuberculous and fungal meningitis, some acute viral CNS infections, and subacute sclerosing panencephalitis (SSPE), a chronic encephalitis caused by measles virus. Further, in instances where the specificity of CSF OGBs is known, these bands represent antibody directed against the agent that causes disease. For example, the OGBs in the CSF of patients with SSPE are antibody directed against measles virus (4), while the oligoclonal IgG in mumps meningitis represents mumps virus-specific antibody (5). In cryptococcal meningitis, the OGBs are adsorbed specifically with cryptococcal antigen, but not with candida antigen (6), and the OGBs in the CSF of patients with HTLV-1 myelopathy contain anti-HTLV-1 p24 antibody (7). Most recently, the oligoclonal $\operatorname{IgG}$ in CSF during varicella zoster virus (VZV) vasculopathy was shown to be antibody directed against VZV (8). An overview of the specificity of OGBs in CNS infectious disorders is provided in Gilden et al. (9). A further link between OGBs and infectious agents as their antigenic targets is offered by the prototypic immunopathology of chronic relapsing experimental autoimmune encephalomyelitis (EAE), produced in guinea pigs inoculated with homologous spinal cord; most of the oligoclonal IgG of these animals was removed by incubation with Mycobacterium tuberculosis contained in the Freund's adjuvant used to help induce disease (10). Together, these findings point to the possibility that the major oligoclonal IgG in the CSF of MS patients may represent antibody to an infectious agent. This is consistent with failures to adsorb out OGBs in MS CSF with myelin or purified myelin proteins. Finally, progressive multifocal leukoencephalopathy is an exclusively human viral induced demyelinating disease (11) without any evidence of immunopathology or autoimmunity.

\section{ANTIBODY IN MS}

The pathologic hallmark of disease is the plaque, an area of white matter demyelination usually accompanied by inflammation. The inflammatory infiltrates are composed of $\mathrm{T}$ lymphocytes, some B cells and plasma cells, as well as activated macrophages or microglial cells. IgG and complement are localized primarily at the periphery of plaques (12). Although it is generally believed that inflammation is an obligatory and possibly primary feature of demyelination in MS, myelin destruction may also proceed in a context nearly devoid of lymphocytic infiltration, suggesting a role for endogenous glia (microglia or astrocytes) in mediating injury (13).

The immune response in MS suggests a possible role for antibody in the pathogenesis of disease. B cells and plasma cells are readily detected in active and late-stage MS lesions $(14,15)$, and histological studies reveal an association of plaque Ig and complement (reviewed in Archelos et al., ref. 16). Macrophages actively engaged in myelin breakdown and contacting myelin sheaths at the plaque margin, but not elsewhere within the same MS lesion, show capping of surface IgG, implicating IgG-antigen complexes in myelin breakdown (17). Furthermore, oligodendrocytes, which undergo destruction in fresh MS plaques (18) are found within reactive astrocytes, and these cells stain positive for IgG (19). Complement proteins have also been found to co-localize with IgG in active MS lesions $(20,21)$. In secondary progressive MS, linear groups of microglia engage short segments of disrupted myelin associated with deposits of complement, and intense staining for IgG is seen throughout the demyelinated zone. Applying multifactorial cluster analysis to very early MS lesions, Gay et al. (22) suggested that the primary lesion in MS is mediated by activated microglia and macrophages containing membrane-bound fixed complexes of both $\mathrm{IgG}$ and complement $\mathrm{C} 3 \mathrm{~d}$. More recently, the activated terminal lytic complex of complement as identified by antibody to the cryptic $\mathrm{C} 9$ neo antigen was found exclusively co-deposited with $\operatorname{IgG}$ in areas of ongoing myelin breakdown $(23,24)$. Additionally, C9 neo and $\mathrm{IgG}$ are found in macrophages containing myelin debris in active MS lesions, providing 
evidence of a direct role for complement in myelin breakdown (23). This notion is further supported by the presence of membrane attack complex-enriched membrane vesicles in MS CSF (25). Finally, a detailed histological analysis of 135 active MS lesions from 83 autopsy and biopsy specimens revealed that the most prominent pathological abnormality was demyelination associated with codeposition of $\operatorname{IgG}$ and activated complement (24).

\section{AUTOIMMUNITY}

Many investigators postulate an autoimmune basis for MS, based largely on analogy with the prototype immunopathology, EAE, as well as the detection in MS of autoreactive T cells and antibodies to various autoantigens. However, proof is wanting. EAE is a T cell-mediated demyelinating disease that can be induced in susceptible rodents and primates by immunization with homogenates of brain or myelin components and adjuvants $(26,27)$. EAE is readily produced in syngeneic recipients by adoptive transfer of lymphocytes from animals sensitized with whole brain white matter or myelin basic protein (MBP), and antibodies to myelin components may contribute to the pathology $(28,29)$. However, adoptive transfer of lymphocytes from MS patients to susceptible mice has rarely induced demyelination (30,31), and there is only a single report of demyelination produced by passive transfer of antibody from MS patients (32). Although MS is considered by some investigators as a strictly CD4+ T cell-mediated disease, histopathologic studies of active lesions indicate a more complex pattern of disease and implicate additional or alternative modes of demyelination in the pathogenesis of MS (24). Also, it has never been shown that abundant brain white matter proteins, such as MBP or myelin oligodendrocyte glycoprotein (MOG), bind to or adsorb out the OGBs in MS. Careful examination of plaques from patients with progressive MS has not revealed IgG binding to the surface of intact myelin sheets, even in the presence of IgG-positive plasma cells (33); thus if anti-myelin antibody contributes to myelin breakdown in chronic MS lesions, the determinant does not appear to be an antigen on the surface of intact healthy myelin sheaths. The collective abundant data gathered on immunogenetic background, macrophage function, specific T-cell subpopulations and cytokine and chemokine responses in EAE and in MS patients has failed to clarify the nature of disease production.

Equally discouraging is that the multiple immunosuppressive and immunomodulating agents used to treat MS have not produced the gratifying response often seen in myasthenia gravis, a proven autoimmune disease. MS is also believed to be immunopathologic or autoimmune based on the ability of various interferons to modify disease in study periods of 3 years or less $(34,35)$. Putative mechanisms (reviewed in Noseworthy et al., ref. 36) include the reduction of $\mathrm{T}$ cell proliferation and the production of tumor necrosis factor-alpha, altered cytokine production, increased secretion of interleukin-10, and reduction of the passage of immune cells across the blood brain barrier by affecting adhesion molecules, chemokines and proteases. However, interferons are proteins produced by cells shortly after virus infection, so that the benefit, if any, of synthetic interferons in MS might rest in their ability to suppress chronic or intermittent virus infection (37). For example, acyclovir, an effective antiviral drug used to treat infection produced by multiple herpesviruses, reduced the incidence of exacerbations by $34 \%$ compared to placebo when MS patients took $800 \mathrm{mg}$ of acyclovir three times daily for 2 years (38). Although seemingly heretical, it was recently suggested that a moratorium be placed on the autoimmune hypothesis in MS to redirect funds for research on novel approaches to the problem (39). 


\section{B CELL TARGETS}

\subsection{General considerations}

Although antibodies to multiple infectious and autoantigens have been found in MS patients, the specificity of the oligoclonal IgG in MS brain and CSF remains unknown. Logical questions arise about whether antibody is (a) specific for disease, i.e., part of the host immune response to the agent that causes MS; (b) a major component of the immune response, particularly in the CNS; and (c) part of a non-beneficial host immune response and related to pathogenesis. Controls for antibodies that are secondary to the disease process have been lacking in many studies of MS, and must be considered in future studies. The detection of specific antibodies in MS patients, but not in control patients with CNS disease assumes significance only when the control patients have inflammatory CNS disease. Furthermore, a characteristic feature of MS is the presence of OGBs in CSF that are absent in blood $(40,41)$. Resolution of brain and CSF proteins by isolectric focusing reveals both polyclonal $\mathrm{IgG}$, as seen in the CNS of healthy patients, as well as oligoclonal IgG, visualized as discrete bands in the cathodal region of the gels. The absence of several of these OGBs in matched serum samples is evidence of intrathecal synthesis. Finally, the contribution of antibody reactivity to the total host immune response must be analyzed. Since the major oligoclonal response in infectious diseases of the nervous system is directed against the agent that causes disease, every attempt must be made to determine the specificity of the oligoclonal IgG in MS. Antibodies to various infectious agents and autoantigens that are not part of the oligoclonal IgG repertoire are likely to be irrelevant, although the demonstration of a direct link between such minor antibody responses and the disease process would be significant. Meanwhile the detection of any antibody in MS that is synthesized intrathecally is worthy of further study.

\subsection{Autoimmune targets}

Many studies have identified autoantibodies directed against CNS antigens in MS patients $(16,42,43)$. However, these anti-brain antibodies are not restricted to MS. For example, Traugott et al. (44) detected anti-brain antibodies, as evidenced by their ability to stain oligodendrocytes or astrocytes from bovine or human brain sections, in $63 \%$ of MS sera, in $43 \%$ of patients with other neurological diseases (both inflammatory and noninflammatory) and in $29 \%$ of normal patients. In the same study, sera from about $50 \%$ of stroke patients stained oligodendrocytes (44). Initially, anti-myelin antibodies were found in serum of $88 \%$ of normal adults, with a "somewhat higher titer in sera from patients with amyotrophic lateral sclerosis (88\%) and MS (100\%)" (45). Steck and Link (46) detected antioligodendrocyte antibodies and antibody levels in CSF and serum of $12 \mathrm{MS}$ patients that did not differ significantly from 25 control patients, including 10 with aseptic meningitis and 7 with cerebrovascular disease. The presence of anti-myelin antibodies in patients with stroke probably reflects antibody to brain antigens released from an immunologically privileged site. Other studies have reported autoantibodies to specific brain antigens (summarized below), although these antibodies are also not MS-specific.

5.2.1. Myelin basic protein-The most extensively studied candidate autoantigen in MS is myelin basic protein (MBP), found at the cytoplasm-membrane interface of oligodendrocytes and comprising $30 \%$ of CNS myelin $(47,48)$. Increased antibody titers to MBP or MBP peptides were detected by radioimmunoassay in 17-96\% of MS CSF and were related to disease activity $(49,50)$. But apart from increased activity in $88 \%$ of patients with optic neuritis, no control CSFs were examined in these studies. Further, an immunospot assay detected antibodies to MBP in CSF of $89 \%$ of MS patients, compared to $67 \%$ of optic neuritis patients and $22 \%$ of patients with other neurological diseases including two patients with inflammatory conditions (Lyme neuroborreliosis and retinochorioidosis) (51). Olsson 
et al. (52) also found similar proportions of anti-MBP or anti-myelin IgG-producing cells in CSF from 27 of 34 (79\%) MS patients, but also found both in CSF from 4 of 14 (29\%) control patients with acute aseptic meningoencephalitis. The greater number of antibodies to MBP and anti-myelin IgG-producing cells in MS most likely reflects the chronic nature of MS, with more antibody production over time compared to a monophasic infectious disorder. More recently, immunoblotting and ELISA demonstrated anti-MBP reactivity in sera of $28 \%$ of MS patients, compared to $47 \%$ of patients with other infectious neurologic diseases, $23 \%$ of other non-infectious neurologic diseases, and $60 \%$ of rheumatoid arthritis patients; noting the enhanced anti-MBP responses in the infectious and inflammatory disease control subjects, the authors suggested that MBP reactivity was not specific for MS (53).

Cruz et al. (54) linked the anti-MBP reactivity in MS CSF to minor bands that were part of the polyclonal response in about one-third of MS patients. More recently, O'Connor et al. (55) attempted to characterize the affinity of anti-MBP antibodies in serum and CSF of MS patients using a solution-phase radioimmunoassay, which is less likely to detect low-affinity antibody/antigen interactions that might be due to excess antigen fixed to a plate or multimeric presentation in a solid-phase ELISA; they only detected autoantibodies to MBP by ELISA, suggesting that moderate- or high-affinity antibodies against MBP were not expressed in MS patients. The detection of low-affinity or low-level anti-MBP antibodies in MS is consistent with other studies that failed to detect anti-MBP antibodies in the CSF by various methods $(56,57)$. The disparities in measuring anti-MBP activity in MS patients, combined with the widespread detection of activity in control groups, indicate that anti-MBP antibodies are not specific for MS.

\subsubsection{Myelin/oligodendrocyte glycoprotein (MOG)—MOG is a strongly}

immunogenic but minor component of myelin that is expressed exclusively on the outermost lamella of the myelin sheath (48). MOG is a dominant target for the demyelinating autoantibody in EAE induced by immunization with CNS homogenates $(58,59)$. Antibodies to MOG have been identified by ELISA and immunoblotting in CSF of only 7 of 30 (23\%) MS patients compared to 2 of 30 (7\%) patients with other neurologic diseases (60). The additional detection of antibody to MOG in CSF of one patient with encephalitis and one with cerebrovascular disease raises the possibility that anti-MOG activity is secondary to tissue destruction. Genain et al. (61) identified myelin degeneration in three MS brains by colocalization of gold-labeled MOG peptides, presumably by their binding to anti-MOG antibody. No MOG-labeled plasma cells were found in brain, although others have reported sequestration of MOG-specific B-cells in brain (62). However, other studies did not find a significantly higher prevalence or level of anti-MOG antibody in CSF of MS patients compared to patients with other neurologic diseases $(53,63)$. A recent attempt to attribute the demyelinating activity in MS patients to anti-MOG antibodies, by linking particular MOG epitopes to MS that are associated with demyelination in EAE, revealed such specificities in the serum from only 1 of 17 MS patients (64). Most recently, another study linked antiMOG antibodies to more rapid development of clinically definite MS in patients after a first demyelinating event (65). Overall, anti-MOG antibodies may simply represent a secondary rather than a causative effect in instances of more severe demyelination.

5.2.3. Other myelin antigens-Other myelin antigens have been studied in MS. The 2', 3' -cyclic nucleotide 3' phosphodiesterase (CNP1), present on the surface of oligodendrocytes, has been described as a major autoantigen for CSF IgM in MS patients and reacted with serum antibody in 52 of 70 (74\%) MS patients compared to 3 of 33 (9\%) patients with other neurologic diseases (66). However, the specificity of the immune response to CNP1 was assessed with highly enriched fractions of CNP. In addition, the antiCNP1 activity, defined as the amount of CNP1 that co-purified with CSF antibody, was 
compared only to MBP that copurified with CSF Ig and not to the entire mixture of purified antigens, questioning whether CNP1 is the most prevalent antigen. Further, no $\operatorname{IgG}$ response to CNP1 was found, although IgG comprises the major oligoclonal response in MS CSF $(67,68)$. Warren et al. $(50)$, using solid-phase radioimmunoassay (RIA) to examine the antibody response in CSF to the most abundant myelin component, proteolipid protein (PLP), detected anti-PLP reactivity in CSF from 9 of 385 patients with MS (2\%), compared to 6 of $55(11 \%)$ patients with optic neuritis, and no other control patients were tested. An additional study found only 5 of 370 (1\%) MS patients with elevated anti-PLP in their CSF (49). For myelin-associated glycoprotein (MAG), solid-phase RIA revealed a statistically significant two-fold increase in anti-MAG activity in CSF from 10 MS patients compared to 12 SSPE patients, 14 patients with other neurological diseases and 10 normal controls. However this reactivity was detected only in CSF and only with the most sensitive technique (RIA) applied (69), suggesting a low level of immunity to MAG. Andersson et al. (70) also identified increased humoral reactivity to MAG in MS patients, as well as in patients with polyneuropathy, but disease could not be correlated with particular MAG peptide epitopes. In 7 patients with relapsing-remitting MS, immunoblotting identified antibodies in CSF that recognized a band corresponding to the oligodendrocyte-specific protein (OSP), as well as additional uncharacterized bands; this reactivity was not seen in two non-inflammatory control CSFs (71). In additional screens using ELISA, 80\% of relapsing-remitting MS patients had anti-OSP values that were above an arbitrary setting of 0.55 , with all 20 control CSFs below the value. However, the authors were not able to correlate anti-OSP reactivities to secondary progressive MS patients.

5.2.4. Other autoantigens-Autoantigens in addition to myelin-specific antigens have been reported in MS, several of which are not CNS-specific. These antigens include a, $\beta$ crystallin (72), heat-shock proteins (73), transaldolase (74,75), proteasomes (76), and DNA (77). Other studies found no increased responses in MS patients or disease specificity for several of these autoantigens $(78,79)$. Overall, a convincing link between any autoimmune antigen and the pathogenesis or major humoral response in MS has not been established.

\subsection{Infectious agents as antigens}

Various microorganisms have been associated with MS, but none has been tightly linked to disease (80). Although intrathecal synthesis of antibodies against viruses has been a common finding $(81,82)$, including early reports of reactivities to measles virus, rubella, mumps, parainfluenza 1 , herpes simplex, varicella, and vaccinia (83-85), these reactivities were attributed to only some patients or a minor fraction of the intrathecally synthesized $\operatorname{IgG}$ in MS, and did not correlate with disease duration or severity $(4,86,87)$.

5.3.1. Herpesviruses-In the past decade, two human herpesviruses have also been associated with MS. One is human herpesvirus-6 (HHV-6), the cause of roseola, and the other is Epstein-Barr virus (EBV), which causes infectious mononucleosis (88-92). The detection of fingerprints of these two ubiquitous viruses known to be latent in blood B(EBV) or T- (HHV-6) cells is intriguing, since the primary encounter with either virus usually occurs before or during puberty, the same time that epidemiologic evidence indicates exposure to the disease-causing agent of MS. However, HHV-6 is found not only in brain and CSF of MS patients, but also in neoplastic and normal brain (93), suggesting that the detection of virus reflects its reactivation from latency and/or blood T-cells trafficking through brain. Other reports do not support an association between HHV-6 and MS. One study found serum IgM responses to HHV-6 in only 1 of 55 MS patients, and IgG responses in 15 of the patients (94). Using PCR, other groups have not detected HHV-6 in MS, and have not shown HHV-6 antibody titers different from those in controls $(95,96)$. Furthermore, no EBV-specific RNA was detected in 10 MS brains by in situ hybridization (97). 
5.3.2. Retroviruses-Several groups have studied the human endogenous retrovirus HERV-H in MS (98), which is an element of the human genome. Activation of HERV-H was detected when specific cell types (mainly B cells) of MS patients were cultivated in vitro (99), and the virus was isolated from a clonal line of leptomeningeal cells from an MS patient (100). Elevated levels of antibodies against HERV-H peptides have been found in the serum and CSF MS patients (101), although a detailed study of MS patients in Sardinia identified HERV-H not only in the CSF of $50 \%$ of MS patients, but also in $40 \%$ of control patients (102). HERV-H is also occasionally present in synovial fluid of rheumatoid arthritis patients (103). Overall, HERV-H is not strongly linked to MS and its detection may reflect the inflammatory response.

5.3.3. Chlamydia-The most recent organism to be implicated is Chlamydia pneumoniae, a gram-negative bacterium. Since the original detection of C. pneumoniae DNA and antibody in CSF of some MS patients (104), various laboratories around the world attempted to confirm this potentially important finding. However, multiple studies have indicated a lack of any significant association between Chlamydia pneumoniae and MS (reviewed in Tsai and Gilden, ref. 105).

\subsection{Potential for infectious agent discovery}

Although early attempts have failed to identify the putative "MS virus" by cocultivation and fusion of MS brain cells with indicator cells, or by inoculation of MS brain into experimental animals (reviewed in Gilden et al., ref. 9), the search for virus needs to be continued. The potential to identify rare or low-abundance pathogens has improved, and the molecular virologic strategies and techniques available today allow studies of virus detection not possible 20 years ago. For example, the ability to prepare and characterize libraries of genes from human tissue based on a difference in their genes or gene products allowed the isolation of cDNA clones derived from hepatitis-C virus (HCV), without prior knowledge of the virus, the viral genome, or presence of circulating viral antibodies (106). Of particular interest is that the abundance of HCV-specific RNA from infected animals was ultimately determined to be only $\sim 0.00001 \%$ or $1: 10^{7}$. Combined cloning in expression vectors (even without subtraction hybridization) and immunologic screening led to the identification of an $\mathrm{HCV}$-specific clone in $\sim 10^{6}$ recombinant phage (106). These sensitive techniques may detect a novel or low-abundance pathogen in MS patients that triggers disease and becomes the major target for the oligoclonal response.

\section{IMPORTANCE OF B CELLS TO DISEASE}

Although the role of B cells in the pathogenesis of MS is still unknown, it is possible that B cells and plasma cells produce antibody against an as yet unidentified infectious agent (antigen) that causes MS. These cells might also produce autoantibodies against specific myelin antigens to damage myelin membranes, or autoantibodies that participate in antiidiotypic networks that might regulate the course of MS (43). The presence of IgG in the CNS of MS patients has been well established, but IgG binding to the surface of intact myelin sheaths, even in the immediate presence of IgG-positive plasma cells, has not been confirmed. These findings, together with the fact that complement coupling dramatically increases the immunogenicity of potential antigens (107), point to the presence of a cryptic antigen located within disrupted myelin close to plaques as the source of the putative MS antigen (33).

\subsection{Characterization of the $B$ cell response}

Mattson et al. $(108,109)$ showed by isoelectric fousing that the OGB profiles in different plaques of the same MS brain overlap but are not identical at each plaque, in contrast with 
SSPE patients in whom OGBs from different brain regions revealed almost identical patterns. Some investigators have attributed this pattern of $\mathrm{IgG}$ expression in MS brain and the apparent absence of OGB specificity to non-specific or bystander-activation of B cells randomly recruited into the CNS (110). However, the somatic mutation and repertoire shifts that occur in antibodies after repeated exposure to antigen might also produce the different OGB profiles.

To further address the significance of the humoral response in MS, several laboratories, including ours, have used PCR methodologies to amplify and analyze the variable region sequences of immunoglobulins (Igs) produced by plasma cells and B cells in MS lesions and CSF. Analysis of heavy chain variable region $(\mathrm{VH})$ sequences expressed in plaque regions of several MS brains revealed a restricted Ig repertoire indicative of a targeted humoral response (111-114). Oligoclonal VH populations were readily detected in each of the MS repertoires and displayed features indicative of affinity maturation, including extensive somatic mutation and the preferential accumulation of replacement mutations in complementarity-determining regions. In one MS brain, $\sim 33 \%$ of the IgG transcripts comprised a single clonal population, and many of the dominant $\mathrm{VH}$ sequences from this brain were found in multiple plaque sites (111). Intraclonal diversification indicative of clonally expanded B cell populations and the preferential utilization of specific family germline segments were also observed in many of the MS repertoires. A comparison of $\mathrm{VH}$ sequences from MS plaques and those in SSPE brain revealed no significant differences in the degree or character of somatic mutations (113). The humoral response in SSPE brain is an antigen-driven response directed against measles virus, the cause of disease, and several of the prominent IgG populations in the SSPE brains studied have been demonstrated to react with specific measles virus proteins $(115,116)$.

Clonally expanded B cell populations have also been detected in the CSF of MS patients and inflammatory neurologic controls (including acute disseminated encephalomyelitis and viral encephalitis), but not in all non-inflammatory neurologic control CSFs (including migraine, amyotrophic lateral sclerosis, and spinocerebellar degeneration, postinfectious myelitis, and epilepsy) (117-120). As in plaque regions, the CSF VH repertoire is restricted, and sequence analysis reveals extensive somatic mutation and intraclonal diversification. Furthermore, the accumulation of intrathecal B cell clones occurs early in disease. Features of the VH repertoire found in MS plaques and CSF are also detected in the CSF of some individuals sampled during their first clinical attack (clinically isolated syndrome). A subsequent follow-up of these subjects shows a high conversion rate to definite MS for those patients with prominent B cell clonal expansion (118).

The antibodies expressed in MS plaques and CSF appear to be preferentially targeted to the CNS. Colombo et al. (119) found that two of the three most overrepresented VH sequences in MS CSF were not amplified from blood lymphocytes using clone-specific PCR primers, and a comparison of the $\mathrm{IgG}$ repertoire of an MS plaque to that in peripheral blood lymphocytes of the same MS patient revealed no overlap between the two VH repertoires (114).

The combined use of fluorescence-activated cell sorting or microdissection techniques with PCR has enabled the single-cell analysis of the rearranged heavy and light chain variable regions of antibodies in B and plasma cells $(121,122)$. Using this approach, our group sorted the CD19+ B cell population in the CSF of several MS patients and amplified the V region sequences of single B cells by RT-PCR. Confirming the conclusions drawn from previous analyses, clonally expanded B cell populations were readily detected in all of the MS patients (120). The most important implication of identifying rearranged heavy and light chain V-region sequences at the single-cell level is the ability to accurately recreate 
recombinant Abs from those populations, which can then be used to search for diseaserelevant antigens in MS.

\section{PERSPECTIVE}

A major challenge will be to identify relevant Ig produced by B or plasma cells. The antibody in MS plaques might be directed against the causative infectious agent or against a relevant autoantigen, whereas some Ig will be directed against an irrelevant antigen(s) released from the brain during destruction. Both relevant and irrelevant antibodies may be likely since memory B cells that are able to switch their antibody specificity away from the immunizing antigen can be maintained over long periods of time (123). Despite the great number of studies of the B cell response in MS, the targets of the oligoclonal response have yet to be determined. This oligoclonal response, one of the diagnostic hallmarks of MS, is likely to provide valuable insights into the cause or pathogenesis of this debilitating disease.

\section{Acknowledgments}

Supported in part by Public Health Service Grants NS 32623 and NS 41549 from the National Institutes of Health. We thank Marina Hoffman for editorial review and Cathy Allen for preparing the manuscript.

\section{REFERENCES}

1. Kurtzke JF, Bui QH. Multiple sclerosis in a migrant population: 2. Half-orientals immigrating in childhood. Ann Neurol. 1980; 8:256-260. [PubMed: 7436368]

2. Kurtzke JF, Delasnerie-Laupretre N, Wallin MT. Multiple sclerosis in North African migrants to France. Acta Neurol Scand. 1998; 98:302-309. [PubMed: 9858098]

3. Spielman RS, Nathanson N. The genetics of susceptibility to multiple sclerosis. Epidemiol Rev. 1982; 4:45-65. [PubMed: 6754409]

4. Vandvik B, Norrby E, Nordal HJ, Derge M. Oligoclonal measles virus-specific IgG antibodies isolated from cerebrospinal fluids, brain extracts, and sera from patients with subacute sclerosing panencephalitis and multiple sclerosis. Scand J Immunol. 1976; 5:979-992. [PubMed: 996452]

5. Vandvik B, Norrby E, Steen-Johnsen J, Stensvold K. Mumps meningitis: prolonged pleocytosis and occurrence of mumps virus-specific oligoclonal IgG in the cerebrospinal fluid. Eur Neurol. 1978; 17:13-22. [PubMed: 624293]

6. Porter KG, Sinnamon DG, Gillies RR. Cryptococcus neoformans-specific oligoclonal immunoglobulins in cerebrospinal fluid in Cryptococcal meningitis. Lancet. 1977; 1:1262. [PubMed: 68362]

7. Grimaldi LME, Roos RP, Devare SG, Casey JM, Maruo Y, Hamada T, Tashiro K. HTLV-1associated myelopathy: oligoclonal immunoglobulin $\mathrm{G}$ bands contain anti-HTLV-1 p24 antibody. Ann Neurol. 1988; 24:727-731. [PubMed: 3207356]

8. Burgoon MP, Hammack BN, Owens GP, Mayback AL, Eikelenboom MJ, Gilden DH. Oligoclonal immunoglobulins in cerebrospinal fluid during varicella zoster virus (VZV) vasculopathy are directed against VZV. Ann Neurol. 2003; 54:459-463. [PubMed: 14520657]

9. Gilden DH, Devlin ME, Burgoon MP, Owens GP. The search for virus in multiple sclerosis brain. Multiple Sclerosis. 1996; 2:179-183. [PubMed: 9345371]

10. Glynn P, Weedon D, Edwards J, Suckling AJ, Cuzner ML. Humoral immunity in chronic relapsing experimental autoimmune encephalomyelitis: the major oligoclonal $\mathrm{IgG}$ bands are antibodies to mycobacteria. J Neurol Sci. 1982; 57:369-384. [PubMed: 6186775]

11. Padgett BL, Walker DL, ZuRhen GM, Eckroade RJ, Dessel BH. Cultivation of papova-like virus from human brain with progressive multifocal leucoencephalopathy. Lancet. 1971; 1:1257-1260. [PubMed: 4104715]

12. Lumsden CE. The immunogenesis of the multiple sclerosis plaque. Brain Res. 1971; 28:365-390. [PubMed: 4939243] 
13. Lassmann H, Raine CS, Antel J, Prineas JW. Immunopathology of multiple sclerosis: report on an international meeting held at the Institute of Neurology of the University of Vienna. $\mathbf{J}$ Neuroimmunol. 1998; 86:213-217. [PubMed: 9663568]

14. Esiri MM. Immunoglobulin-containing cells in multiple sclerosis plaques. Lancet. 1977; 2:478480. [PubMed: 70689]

15. Prineas, JW. The neuropathology of multiple sclerosis. In: Vinken, PJ.; Bruyn, GW.; Klawans, HL.; Koetsier, JC., editors. Handbook of Clinical Neurology. Vol. Vol. 3. Amsterdam-New York: Elsevier Science Publishers; 1985. p. 213-257.

16. Archelos JJ, Storch MK, Hartung HP. The role of B cells and autoantibodies in multiple sclerosis. Ann Neurol. 2000; 47:694-706. [PubMed: 10852535]

17. Prineas JW, Graham JS. Multiple sclerosis: capping of surface immunoglobulin G on macrophages engaged in myelin breakdown. Ann Neurol. 1981; 10:149-158. [PubMed: 7025748]

18. Prineas JW, Kwon EE, Goldenberg PZ, Ilyas AA, Quarles RH, Benjamins JA, Sprinkle TJ. Multiple sclerosis: oligodendrocyte proliferation and differentiation in fresh lesions. Lab Invest. 1989; 61:489-503. [PubMed: 2811298]

19. Prineas JW, Kwon EE, Goldenberg PZ, Cho E-S, Sharer LR. Interaction of astrocytes and newly formed oligodendrocytes in resolving multiple sclerosis lesions. Lab Invest. 1990; 63:624-636. [PubMed: 1700195]

20. Woyciechowska JL, Brzosko WJ. Immunofluorescence study of brain plaques from two patients with multiple sclerosis. Neurology. 1977; 27:620-622. [PubMed: 559966]

21. Gay D, Esiri M. Blood-brain barrier damage in acute multiple sclerosis plaques. An immunocytological study. Brain. 1991; 114:557-572. [PubMed: 2004256]

22. Gay FW, Drye TJ, Dick GW, Esiri MM. The application of multifactorial cluster analysis in the staging of plaques in early multiple sclerosis. Identification and characterization of the primary demyelinating lesions. Brain. 1997; 120:1461-1483. [PubMed: 9278635]

23. Storch MK, Piddlesden S, Haltia M, Iivanainen M, Morgan P, Lassmann H. Multiple Sclerosis: in situ evidence for Ab- and complement-mediated demyelination. Ann Neurol. 1998; 43:465-471. [PubMed: 9546327]

24. Lucchinetti C, Bruck W, Parisi J, Scheithauer B, Rodriguez M, Lassmann H. Heterogeneity of multiple sclerosis lesions: Implications for the pathogenesis of demyelination. Ann Neurol. 2000; 47:707-717. [PubMed: 10852536]

25. Scolding NJ, Morgan BP, Houston WA, Linington C, Campbell AK, Compston DA. Vesicular removal by oligodendrocytes of membrane attack complexes formed by activated complement. Nature. 1989; 339:620-622. [PubMed: 2733792]

26. Bernard CC, Carnegie PR. Experimental autoimmune encephalomyelitis in mice: immunologic response to mouse spinal cord and myelin basic proteins. J Immunol. 1975; 115:1537-1540. [PubMed: 47366]

27. Owens T, Sriram S. The immunology of multiple sclerosis and its animal model, experimental allergic encephalomyelitis. Neurol Clin. 1995; 13:51-73. [PubMed: 7739505]

28. Linington C, Engelhardt B, Kapocs G, Lassman H. Induction of persistently demyelinated lesions in the rat following the repeated adoptive transfer of encephalitogenic $\mathrm{T}$ cells and demyelinating antibody. J Neuroimmunol. 1992; 40:219-224. [PubMed: 1385471]

29. Genain CP, Nguyen MH, Letvin NL, Pearl R, Davis RL, Adelman M, Lees MB, Linington C, Hauser SL. Antibody facilitation of multiple sclerosis-like lesions in a nonhuman primate. J Clin Invest. 1995; 96:2966-2974. [PubMed: 8675668]

30. Jones RE, Chou Y, Young A, Mass M, Vandenbark A, Offner H, Bourdette D. T cells with encephalitogenic potential from multiple sclerosis patients and Lewis rats fail to induce disease in SCID mice following intracisternal injection. J Neuroimmunol. 1995; 56:119-126. [PubMed: 7860707]

31. Lavi E, Rostami A. Demyelination following transfer of human lymphocytes into mice with severe combined immunodeficiency. Pathobiology. 1996; 64:136-141. [PubMed: 8910922]

32. Saeki Y, Mima T, Sakoda S, Fujimura H, Arita N, Nomura T, Kishimoto T. Transfer of multiple sclerosis into severe combined immunodeficiency mice by mononuclear cells from cerebrospinal fluid of the patients. Proc Natl Acad Sci USA. 1992; 89:6157-6161. [PubMed: 1631103] 
33. Prineas JW, Kwon EE, Cho E-S, Sharer LR, Barnett MH, Oleszak EL, Hoffman B, Morgan BP. Immunopathology of secondary-progressive multiple sclerosis. Ann Neurol. 2001; 50:646-657. [PubMed: 11706971]

34. Paty DW, Li DK. UBC MS/MRI Study Group \& IFNB Multiple Sclerosis Study Group. Interferon beta-1b is effective in relapsing-remitting multiple sclerosis. II. MRI analysis results of a multicenter, randomized, double-blind, placebo-controlled trial. Neurology. 1993; 43:662-667. [PubMed: 8469319]

35. Jacobs LD, Beck RW, Simon JH, Kinkel P, Brownscheidle CM, Murray TJ, Simonian NA, Slasor PJ, Sandrock AW. the CHAMPS Study Group. Intramuscular interferon beta-1a therapy initiated during a first demyelinating event in multiple sclerosis. N Engl J Med. 2000; 343:898-904. [PubMed: 11006365]

36. Noseworthy JH, Lucchinetti C, Rodriguez M, Weinshenker BG. Multiple sclerosis. N Engl J Med. 2000; 343:938-952. [PubMed: 11006371]

37. Weinstock-Guttman B, Ransohoff RM, Kinkel RP, Rudick RA. The interferons: biological effects, mechanisms of action, and use in multiple sclerosis. Ann Neurol. 1995; 37:7-15. [PubMed: 7529476]

38. Lycke J, Svennerholm B, Hjelmquist E, Frisén L, Badr G, Andersson M, Vahlne A, Andersen O. Acyclovir treatment of relapsing-remitting multiple sclerosis: a randomized, placebo-controlled, double-blind study. J Neurol. 1996; 243:214-224. [PubMed: 8936350]

39. Steiner I, Wirguin I. Multiple sclerosis - in need of a critical reappraisal. Med Hypotheses. 2000; 54:99-106. [PubMed: 10790735]

40. Poser CM, Paty DW, Scheinberg L, McDonald WI, Davis FA, Ebers GC, Johnson KP, Sibley WA, Silberberg DH, Tourtellotte WW. New diagnostic criteria for multiple sclerosis: guidelines for research protocols. Ann Neurol. 1983; 13:227-231. [PubMed: 6847134]

41. Poser CM, Brinar VV. Problems with diagnostic criteria for multiple sclerosis. Lancet. 2001; 358:1746-1747. [PubMed: 11734228]

42. Cross AH, Trotter JL, Lyons J-A. B cells and antibodies in CNS demyelinating disease. J Neuroimmunol. 2001; 112:1-14. [PubMed: 11108928]

43. Correale J, de los Milagros Bassani Molinas M. Oligoclonal bands and antibody responses in multiple sclerosis. J Neurol. 2002; 249:375-389. [PubMed: 11967640]

44. Traugott U, Snyder S, Raine CS. Oligodendrocyte staining by multiple sclerosis serum is nonspecific. Ann Neurol. 1979; 6:13-20. [PubMed: 389147]

45. Edgington TS, Dalessio DJ. The assessment by immunofluorescence methods of humoral antimyelin antibodies in man. J Immunol. 1970; 105:248-255. [PubMed: 4193275]

46. Steck AJ, Link H. Antibodies against oligodendrocytes in serum and CSF in multiple sclerosis and other neurological diseases: 125I-protein A studies. Acta Neurol Scand. 1984; 70:81-89. [PubMed: 6485748]

47. Sedzik J, Blaurock AE, Hochli M. Lipid/myelin basic protein multilayers. A model for the cytoplasmic space in central nervous system myelin. J Mol Biol. 1984; 174:385-409. [PubMed: 6201618]

48. Brunner C, Lassmann H, Waehneldt TV, Matthieu JM, Linington C. Differential ultrastructural localization of myelin basic protein, myelin/oligodendroglial glycoprotein, and 2',3'-cyclic nucleotide 3'-phosphodiesterase in the CNS of adult rats. J Neurochem. 1989; 52:296-304. [PubMed: 2462020]

49. Warren KG, Catz I. Relative frequency of autoantibodies to myelin basic protein and proteolipid protein in optic neuritis and multiple sclerosis cerebrospinal fluid. J Neurol Sci. 1994; 121:66-73. [PubMed: 7510787]

50. Warren KG, Catz I, Johnson E, Mielke B. Anti-myelin basic protein and anti-proteolipid protein specific forms of multiple sclerosis. Ann Neurol. 1994; 35:280-289. [PubMed: 7510098]

51. Soderstrom M, Link H, Xu Z, Fredriksson S. Optic neuritis and multiple sclerosis: anti-MBP and anti-MBP peptide antibody-secreting cells are accumulated in CSF. Neurology. 1993; 43:12151222. [PubMed: 7513391]

52. Olsson T, Baig S, Hojeberg B, Link H. Antimyelin basic protein and antimyelin antibodyproducing cells in multiple sclerosis. Ann Neurol. 1990; 27:132-136. [PubMed: 1690527] 
53. Reindl M, Linington C, Brehm U, Egg R, Dilitz E, Deisenhammer F, Poewe W, Berger T. Antibodies against the myelin oligodendrocyte glycoprotein and the myelin basic protein in multiple sclerosis and other neurological diseases: a comparative study. Brain. 1999; 122:20472056. [PubMed: 10545390]

54. Cruz M, Olsson T, Ernerudh J, Hojeberg B, Link H. Immunoblot detection of oligoclonal antimyelin basic protein IgG antibodies in cerebrospinal fluid in multiple sclerosis. Neurology. 1987; 37:1515-1519. [PubMed: 2442667]

55. O'Connor KC, Chitnis T, Griffin DE, Piyasirisilp S, Bar-Or A, Khoury S, Wucherpfennig KW, Hafler DA. Myelin basic protein-reactive autoantibodies in the serum and cerebrospinal fluid of multiple sclerosis patients are characterized by low-affinity interactions. J Neuroimmunol. 2003; 136:140-148. [PubMed: 12620653]

56. Chou CH, Tourtellotte WW, Kibler RF. Failure to detect antibodies to myelin basic protein or peptic fragments of myelin basic protein in CSF of patients with MS. Neurology. 1983; 33:24-28. [PubMed: 6184646]

57. Brokstad KA, Page M, Nyland H, Haaheim LR. Autoantibodies to myelin basic protein are not present in the serum and CSF of MS patients. Acta Neurol Scand. 1994; 89:407-411. [PubMed: 7526591]

58. Lebar R, Lubetzki C, Vincent C, Lombrail P, Boutry JM. The M2 autoantigen of central nervous system myelin, a glycoprotein present in oligodendrocyte membrane. Clin Exp Immunol. 1986; 66:423-434. [PubMed: 2434274]

59. Linington C, Lassmann $\mathrm{H}$. Antibody responses in chronic relapsing experimental allergic encephalomyelitis: correlation of serum demyelinating activity with antibody titre to the myelin/ oligodendrocyte glycoprotein (MOG). J Neuroimmunol. 1987; 17:61-69. [PubMed: 2445777]

60. Xiao BG, Linington C, Link H. Antibodies to myelin-oligodendrocyte glycoprotein in cerebrospinal fluid from patients with multiple sclerosis and controls. J Neuroimmunol. 1991; 31:91-96. [PubMed: 1991822]

61. Genain CP, Cannella B, Hauser SL, Raine CS. Identification of autoantibodies associated with myelin damage in multiple sclerosis. Nat Med. 1999; 5:170-175. [PubMed: 9930864]

62. Sun J, Link H, Olsson T, Xiao BG, Andersson G, Ekre HP, Linington C, Diener P. T and B cell responses to myelin-oligodendrocyte glycoprotein in multiple sclerosis. J Immunol. 1991; 146:1490-1495. [PubMed: 1899688]

63. Karni A, Bakimer-Kleiner R, Abramsky O, Ben Nun A. Elevated levels of antibody to myelin oligodendrocyte glycoprotein is not specific for patients with multiple sclerosis. Arch Neurol. 1999; 56:311-315. [PubMed: 10190821]

64. Haase CG, Guggenmos J, Brehm U, Andersson M, Olsson T, Reindl M, Schneidewind JM, Zettl UK, Heidenreich F, Berger T, Wekerle H, Hohlfeld R, Linington C. The fine specificity of the myelin oligodendrocyte glycoprotein autoantibody response in patients with multiple sclerosis and normal healthy controls. J Neuroimmunol. 2001; 114:220-225. [PubMed: 11240035]

65. Berger T, Rubner P, Schautzer F, Egg R, Ulmer H, Mayringer I, Dilitz E, Deisenhammer F, Reindl M. Antimyelin antibodies as a predictor of clinically definite multiple sclerosis after a first demyelinating event. N Engl J Med. 2003; 349:139-145. [PubMed: 12853586]

66. Walsh MJ, Murray JM. Dual implication of 2',3'- cyclic nucleotide 3' phosphodiesterase as major autoantigen and $\mathrm{C} 3$ complement-binding protein in the pathogenesis of multiple sclerosis. J Clin Invest. 1998; 101:1923-1931. [PubMed: 9576757]

67. Link H, Muller R. Immunoglobulins in multiple sclerosis and infections of the nervous system. Arch Neurol. 1971; 25:326-344. [PubMed: 4999855]

68. Link H, Laurenzi MA. Immunoglobulin class and light chain type of oligoclonal bands in CSF in multiple sclerosis determined by agarose gel electrophoresis and immunofixation. Ann Neurol. 1979; 6:107-110. [PubMed: 115379]

69. Moller JR, Johnson D, Brady RO, Tourtellotte WW, Quarles RH. Antibodies to myelin-associated glycoprotein (MAG) in the cerebrospinal fluid of multiple sclerosis patients. J Neuroimmunol. 1989; 22:55-61. [PubMed: 2465313] 
70. Andersson M, Yu M, Soderstrom M, Weerth S, Baig S, Solders G, Link H. Multiple MAG peptides are recognized by circulating $\mathrm{T}$ and $\mathrm{B}$ lymphocytes in polyneuropathy and multiple sclerosis. Eur J Neurol. 2002; 9:243-251. [PubMed: 11985632]

71. Bronstein JM, Lallone RL, Seitz RS, Ellison GW, Myers LW. A humoral response to oligodendrocyte-specific protein in MS: a potential molecular mimic. Neurology. 1999; 53:154161. [PubMed: 10408552]

72. Agius MA, Kirvan CA, Schafer AL, Gudipati E, Zhu S. High prevalence of anti-alpha-crystallin antibodies in multiple sclerosis: correlation with severity and activity of disease. Acta Neurol Scand. 1999; 100:139-147. [PubMed: 10478576]

73. Birnbaum G, Kotilinek L. Heat shock or stress proteins and their role as autoantigens in multiple sclerosis. Ann N Y Acad Sci. 1997; 835:157-167. [PubMed: 9616771]

74. Banki K, Colombo E, Sia F, Halladay D, Mattson DH, Tatum AH, Massa PT, Phillips PE, Perl A. Oligodendrocyte-specific expression and autoantigenicity of transaldolase in multiple sclerosis. J Exp Med. 1994; 180:1649-1663. [PubMed: 7964452]

75. Colombo E, Banki K, Tatum AH, Daucher J, Ferrante P, Murray RS, Phillips PE, Perl A. Comparative analysis of antibody and cell-mediated autoimmunity to transaldolase and myelin basic protein in patients with multiple sclerosis. J Clin Invest. 1997; 99:1238-1250. [PubMed: 9077532]

76. Mayo I, Arribas J, Villoslada P, Alvarez DR, Rodriguez-Vilarino S, Montalban X, De Sagarra MR, Castano JG. The proteasome is a major autoantigen in multiple sclerosis. Brain. 2002; 125:26582667. [PubMed: 12429593]

77. Williamson RA, Burgoon MP, Owens GP, Ghausi O, Leclerc E, Firme L, Carlson S, Corboy J, Parren PW, Sanna PP, Gilden DH, Burton DR. Anti-DNA antibodies are a major component of the intrathecal B cell response in multiple sclerosis. Proc Natl Acad Sci USA. 2001; 98:1793-1798. [PubMed: 11172030]

78. Celet B, Akman-Demir G, Serdaroglu P, Yentur SP, Tasci B, van Noort JM, Eraksoy M, SaruhanDireskeneli G. Anti-alpha B-crystallin immunoreactivity in inflammatory nervous system diseases. J Neurol. 2000; 247:935-939. [PubMed: 11200685]

79. Gao YL, Raine CS, Brosnan CF. Humoral response to hsp 65 in multiple sclerosis and other neurologic conditions. Neurology. 1994; 44:941-946. [PubMed: 8190301]

80. Johnson, RT. Viral Infections of the Nervous System. 2nd edition. Philadelphia, PA: LippincottRaven; 1998.

81. Norrby E. Viral antibodies in multiple sclerosis. Prog Med Virol. 1978; 24:1-39. [PubMed: 704893]

82. Salmi A, Reunanen M, Ilonen J, Panelius M. Intrathecal antibody synthesis to virus antigens in multiple sclerosis. Clin Exp Immunol. 1983; 52:241-249. [PubMed: 6407791]

83. Forghani B, Cremer NE, Johnson KP, Fein G, Likosky WH. Comprehensive viral immunology of multiple sclerosis. III. Analysis of CSF antibodies by radioimmunoassay. Arch Neurol. 1980; 37:616-619. [PubMed: 6252875]

84. Cremer NE, Johnson KP, Fein G, Likosky WH. Comprehensive viral immunology of multiple sclerosis. II. Analysis of serum and CSF antibodies by standard serologic methods. Arch Neurol. 1980; 37:610-615. [PubMed: 6252874]

85. Rostrom B, Link H, Laurenzi MA, Kam-Hansen S, Norrby E, Wahren B. Viral antibody activity of oligoclonal and polyclonal immunoglobulins synthesized within the central nervous system in multiple sclerosis. Ann Neurol. 1981; 9:569-574. [PubMed: 7259119]

86. Vartdal F, Vandvik B, Norrby E. Viral and bacterial antibody responses in multiple sclerosis. Ann Neurol. 1980; 8:248-255. [PubMed: 6254433]

87. Salmi AA, Norrby E, Panelius M. Identification of different measles virus-specific antibodies in the serum and cerebrospinal fluid from patients with subacute sclerosing pancencephalitis and multiple sclerosis. Infect Immun. 1972; 6:248-254. [PubMed: 4629257]

88. Challoner PB, Smith KT, Parker JD, MacLeod DL, Coulter SN, Rose TM, Schultz ER, Bennett JL, Garber RL, Chang M, Schad PA, Stewart PM, Nowinski RC, Brown JP, Burmer GC. Plaqueassociated expression of human herpesvirus 6 in multiple sclerosis. Proc Natl Acad Sci USA. 1995; 92:7440-7444. [PubMed: 7638210] 
89. Soldan SS, Berti R, Salem N, Secchiero P, Flamand L, Calabresi PA, Brennan MB, Maloni HW, McFarland HF, Lin HC, Patnaik M, Jacobson S. Association of human herpes virus 6 (HHV-6) with multiple sclerosis: increased IgM response to HHV-6 early antigen and detection of serum HHV-6 DNA. Nat Med. 1997; 3:1394-1397. [PubMed: 9396611]

90. Akhyani N, Berti R, Brennan MB, Soldan SS, Eaton JM, McFarland HF, Jacobson S. Tissue distribution and variant characterization of human herpesvirus (HHV)-6: increased prevalence of HHV-6A in patients with multiple sclerosis. J Infect Dis. 2000; 182:1321-1325. [PubMed: 11023456]

91. Sumaya CV, Myers LW, Ellison GW, Ench Y. Increased prevalence and titer of Epstein-Barr virus antibodies in patients with multiple sclerosis. Ann Neurol. 1985; 17:371-377. [PubMed: 2988410]

92. Levin LI, Munger KL, Rubertone MV, Peck CA, Lennette ET, Spiegelman D, Ascherio A. Multiple sclerosis and Epstein-Barr virus. JAMA. 2003; 289:1533-1536. [PubMed: 12672770]

93. Cuomo L, Trivedi P, Cardillo MR, Gagliardi FM, Vecchione A, Caruso R, Calogero A, Frati L, Gaggioni A, Ragona G. Human herpesvirus 6 infection in neoplastic and normal brain tissue. J Med Virol. 2001; 63:45-51. [PubMed: 11130886]

94. Enbom M, Wang FZ, Fredrikson S, Martin C, Dahl H, Linde A. Similar humoral and cellular immunological reactivities to human herpesvirus 6 in patients with multiple sclerosis and controls. Clin Diagn Lab Immunol. 1999; 6:545-549. [PubMed: 10391860]

95. Mirandola P, Stefan A, Brambilla E, Campadelli-Fiume G, Grimaldi LM. Absence of human herpesvirus 6 and 7 from spinal fluid and serum of multiple sclerosis patients. Neurology. 1999; 53:1367-1368. [PubMed: 10522909]

96. Taus C, Pucci E, Cartechini E, Fie A, Giuliani G, Clementi M, Menzo S. Absence of HHV-6 and HHV-7 in cerebrospinal fluid in relapsing-remitting multiple sclerosis. Acta Neurol Scand. 2000; 101:224-228. [PubMed: 10770517]

97. Hilton DA, Love S, Fletcher A, Pringle JH. Absence of Epstein-Barr virus in multiple sclerosis as assessed by in situ hybridisation. J Neurol Neurosurg Psychiatry. 1994; 57:975-976. [PubMed: 7520057]

98. Kolson DL, Gonzalez-Scarano F. Endogenous retroviruses and multiple sclerosis. Ann Neurol. 2001; 50:429-430. [PubMed: 11601492]

99. Clausen J. Endogenous retroviruses and MS: using ERVs as disease markers. Int MS J. 2003; 10:22-28. [PubMed: 12906767]

100. Perron H, Geny C, Laurent A, Mouriquand C, Pellat J, Perret J, Seigneurin JM. Leptomeningeal cell line from multiple sclerosis with reverse transcriptase activity and viral particles. Res Virol. 1989; 140:551-561. [PubMed: 2482522]

101. Christensen T, Sorensen PD, Hansen HJ, Moller-Larsen A. Antibodies against a human endogenous retrovirus and the preponderance of env splice variants in multiple sclerosis patients. Multiple Sclerosis. 2003; 9:6-15. [PubMed: 12617261]

102. Dolei A, Serra C, Mameli G, Pugliatti M, Sechi G, Cirotto MC, Rosati G, Sotgiu S. Multiple sclerosis-associated retrovirus (MSRV) in Sardinian MS patients. Neurology. 2002; 58:471-473. [PubMed: 11839854]

103. Gaudin P, Ijaz S, Tuke PW, Marcel F, Paraz A, Seigneurin JM, Mandrand B, Perron H, Garson JA. Infrequency of detection of particle-associated MSRV/HERV-W RNA in the synovial fluid of patients with rheumatoid arthritis. Rheumatology. 2000; 39:950-954. [PubMed: 10986298]

104. Sriram S, Stratton CW, Yao S, Tharp A, Ding L, Bannan JD, Mitchell WM. Chlamydia pneumoniae infection of the central nervous system in multiple sclerosis. Ann Neurol. 1999; 46:6-14. [PubMed: 10401775]

105. Tsai JC, Gilden DH. Chlamydia pneumoniae and multiple sclerosis: no significant association. Trends Microbiol. 2001; 9:152-154. [PubMed: 11286864]

106. Choo Q-L, Kuo G, Weiner A, Overby L, Bradley D, Houghton M. Isolation of a cDNA clone derived from a blood-borne non-A, non-B viral hepatitis genome. Science. 1989; 244:359-362. [PubMed: 2523562]

107. Fearon DT, Locksley RM. The instructive role of innate immunity in the acquired immune response. Science. 1996; 272:50-53. [PubMed: 8600536] 
108. Mattson DH, Roos RP, Arnason BG. Isoelectric focusing of IgG eluted from multiple sclerosis and subacute sclerosing panencephalitis brains. Nature. 1980; 287:335-336. [PubMed: 7421992]

109. Mattson DH, Roos RP, Arnason BG. Oligoclonal IgG in multiple sclerosis and subacute sclerosing panencephalitis brains. J Neuroimmunol. 1982; 2:261-276. [PubMed: 7085864]

110. Sindic CJM, Monteyne Ph, Laterre EC. The intrathecal synthesis of virus-specific oligoclonal IgG in multiple sclerosis. J Immunol. 1994; 54:75-80.

111. Owens GP, Kraus H, Burgoon MP, Smith-Jensen T, Devlin ME, Gilden DH. Restricted use of $\mathrm{V}_{\mathrm{H}^{4}}$ germline segments in an acute multiple sclerosis brain. Ann Neurol. 1998; 43:236-243. [PubMed: 9485065]

112. Baranzini SE, Jeong MC, Butunoi C, Murray RS, Bernard CC, Oksenberg JR. B cell repertoire diversity and clonal expansion in multiple sclerosis brain lesions. J Immunol. 1999; 163:51335144. [PubMed: 10528220]

113. Smith-Jensen T, Burgoon MP, Anthony J, Kraus H, Gilden DH, Owens GP. Comparison of IgG heavy chain sequences in MS and SSPE brains reveals an antigen-driven response. Neurology. 2000; 54:1227-1232. [PubMed: 10746589]

114. Owens GP, Burgoon MP, Anthony J, Kleinschmidt-DeMasters BK, Gilden DH. The immunoglobulin $\mathrm{G}$ heavy chain repertoire in multiple sclerosis plaques is distinct from the heavy chain repertoire in peripheral blood lymphocytes. Clin Immunol. 2001; 98:258-263. [PubMed: 11161983]

115. Burgoon MP, Williamson RA, Owens GP, Ghausi O, Bastidas RB, Burton DR, Gilden DH. Cloning the antibody response in humans with inflammatory CNS disease: isolation of measles virus-specific antibodies from phage display libraries of a subacute sclerosing panencephalitis brain. J Neuroimmunol. 1999; 94:204-211. [PubMed: 10376954]

116. Burgoon MP, Owens GP, Smith-Jensen T, Walker D, Gilden DH. Cloning the antibody response in humans with inflammatory CNS disease: Analysis of the expressed IgG repertoire in subacute sclerosing panencephalitis brain reveals disease-relevant antibodies that recognize specific measles virus antigens. J Immunol. 1999; 163:3496-3502. [PubMed: 10477623]

117. Qin Y, Duquette P, Zhang Y, Talbot P, Poole R, Antel J. Clonal expansion and somatic hypermutation of $\mathrm{VH}$ genes of B cells from cerebrospinal fluid in multiple sclerosis. J Clin Invest. 1998; 102:1045-1050. [PubMed: 9727074]

118. Qin Y, Duquette P, Zhang Y, Olek M, Da R-R, Richardson J, Antel JP, Talbot P, Cashman NR, Tourtellotte WW, Wekerle H, van den Noort S. Intrathecal B-cell clonal expansion, an early sign of humoral immunity, in the cerebrospinal fluid of patients with clinically isolated syndrome suggestive of multiple sclerosis. Lab Invest. 2003; 83:1081-1088. [PubMed: 12861047]

119. Colombo M, Dono M, Gazzola P, Roncella S, Valetto A, Chiorazzi N, Mancardi G, Ferrarini M. Accumulation of clonally related B lymphocytes in the cerebrospinal fluid of multiple sclerosis patients. J Immunol. 2000; 164:2782-2789. [PubMed: 10679121]

120. Owens GP, Ritchie AM, Burgoon MP, Williamson RA, Corboy JR, Gilden DH. Single-cell repertoire analysis demonstrates that clonal expansion is a prominent feature of the $\mathrm{B}$ cell response in multiple sclerosis cerebrospinal fluid. J Immunol. 2003; 171:2725-2733. [PubMed: 12928426]

121. Brezinschek HP, Brezinschek RI, Lipsky PE. Analysis of the heavy chain repertoire of human peripheral B cells using single-cell polymerase chain reaction. J Immunol. 1995; 155:190-202. [PubMed: 7602095]

122. Kuppers R, Zhao M, Hansmann ML, Rajewsky K. Tracing B cell development in human germinal centres by molecular analysis of single cells picked from histological sections. EMBO J. 1993; 12:4955-4967. [PubMed: 8262038]

123. Maruyama M, Lam K-P, Rajewsky K. Memory B-cell persistence is independent of persisting immunizing antigen. Nature. 2000; 407:636-642. [PubMed: 11034213] 